\title{
Stem cell transplantation as consolidation in peripheral T-cell lymphomas
}

\author{
Manuel Abecasis, Catalina Gomez, Isabelina Ferreira, Maria Gomes da Silva, Nuno Miranda, Gilda Teixeira, \\ Fernando Leal da Costa, Maria João Gutierrez \\ Instituto Português Oncologia de Lisboa Francisco Gentil, Lisboa, Portugal \\ Prof. Dr. Manuel Abecasis, Director, Hematology \\ Department, Instituto Português Oncologia, R. Professor \\ Lima Basto 1099-093, Lisboa, Portugal
}

Citation: Abecasis M, Gomez C, Ferreira I et al. Stem cell transplantation as consolidation in peripheral T-cell lymphomas. Cell Ther Transplant 2020; 9(1): 22-27.

\section{Summary}

Peripheral T-cell lymphomas (PTCLs) are a rare and heterogeneous group of aggressive lymphomas comprising more than 20 different entities and representing about $10 \%$ of all non-Hodgkin lymphomas diagnosed in the Western World. Given their heterogeneity, there is no consensus regarding the best first-line treatment and the role of autologous/allogeneic hematopoietic stem cell transplantation (HSCT) as consolidation is controversial. To examine the real-world outcomes for patients with PTCL submitted to HSCT in our institution we retrospectively reviewed the clinical outcomes of 26 patients who were given a transplant either as first-line consolidation or in relapse between January 2000 and July 2018. The median follow-up is 6.3 years; 19 patients had an autologous HSCT, 16 as upfront consolidation and 3, for relapsed disease. Overall survival (OS) and relapse free survival (RFS) were, respectively, $62 \%$ and $59 \%$. Seven patients had an allograft, 4 as upfront consolidation and 3 after relapse; 6 are alive and 1 died due to transplant-related mortality (TRM). TRM was $3.7 \%$ for the entire population and the 6-year OS and PFS were $74 \%$ and $69 \%$, respectively. Our results suggest that autologous/allogeneic HSCT is an effective and safe option for the consolidation of adverse-risk profile patients with PTCL, but they need to be validated in prospective studies including a larger number of patients.

\section{Keywords}

Peripheral T-cell lymphomas, first-line therapy, CHOP, Brentuximab vedotin, hematopoietic stem cell transplantation, allogeneic, autologous.

\section{Introduction}

Peripheral T-cell lymphomas (PTCLs) derived from post-thymic T cells or mature NK cells, are a rare and heterogeneous group of aggressive lymphomas comprising approximately $10 \%$ of all non-Hodgkin lymphomas diagnosed in the western world. In 2016, the WHO classification of lymphoid neoplasms recognized more than 20 different $\mathrm{T}$-cell lymphoma entities that broadly segregate into lymphomas with predominant nodal involvement, extra-nodal involvement, leukemic, or cutaneous manifestations [1].

Nodal PTCLs are the most common of the PTCL subtypes and include peripheral T-cell lymphoma not otherwise specified (PTCL-NOS), systemic anaplastic large cell lymphoma (sALCL) and angioimmunoblastic T-cell lymphoma (AITL). Together these 3 subtypes account for about $60 \%$ of all PTCL lymphomas. Given their heterogeneity, there is no consensus regarding the best first-line treatment, and the role of autologous/allogeneic (ASCT/alloSCT) stem cell transplantation as consolidation is controversial.

Conventional treatment with CHOP or CHOP-like regimen induces CR in about $50 \%$ of cases, with a 5 -year survival of $30 \%-35 \%[2,3]$. Expected outcomes in terms of 5-year PFS/ EFS in PTCL with initial CHOP treatment are based on 2 large retrospective series: the studies performed by the International T-Cell Project (ITCP) and the British Columbia Cancer Agency (BCCA) $[4,5]$ shown in Table 1.

Although CHOP is the most commonly used first-line regimen for patients with PTCL outcomes are disappointing with the exception of patients with ALK-positive sALCL. The most compelling evidence supporting the benefits of building on CHOP come from studies adding etoposide (CHOEP). 
It appears to offer an advantage over CHOP in younger patients ( $<60$ years) based on a retrospective analysis of 7 prospective phase 2 or 3 German protocols including 343 patients [6]. CHOEP improved EFS from $51 \%$ to $71 \%$. A registry study from Sweden found a superior PFS for CHOEP, also in patients $<60$ years [7]. This was seen particularly in those with ALCL and normal concentrations of lactate dehydrogenase. However, no improvement in OS was revealed, and greater toxicity was observed in older patients. This is also supported by the data from the COMPLETE study and suggests that any overall survival benefit associated with etoposide use in patients with PTCL is at best modest [8].

Table 1. Expected outcomes (5-year PFS) in PTCL subtypes treated with CHOP as first-line therapy $[4,5]$

\begin{tabular}{|l|l|l|l|l|}
\hline Study & N & PTCL - NOS & AITL & $\begin{array}{l}\text { ALCL ALK } \\
\text { negative }\end{array}$ \\
\hline $\begin{array}{l}\text { ITCP } \\
(2008)\end{array}$ & 1314 & $20 \%$ & $18 \%$ & $36 \%$ \\
\hline $\begin{array}{l}\text { BCCA } \\
(2004)\end{array}$ & 199 & $29 \%$ & $13 \%$ & $28 \%$ \\
\hline
\end{tabular}

Although CHOP is the most commonly used first-line regimen for patients with PTCL outcomes are disappointing with the exception of patients with ALK-positive sALCL. The most compelling evidence supporting the benefits of building on $\mathrm{CHOP}$ come from studies adding etoposide (CHOEP). It appears to offer an advantage over CHOP in younger patients ( $<60$ years) based on a retrospective analysis of 7 prospective phase 2 or 3 German protocols including 343 patients [6]. CHOEP improved EFS from $51 \%$ to $71 \%$. A registry study from Sweden found a superior PFS for CHOEP, also in patients $<60$ years [7]. This was seen particularly in those with ALCL and normal concentrations of lactate dehydrogenase. However, no improvement in OS was revealed, and greater toxicity was observed in older patients. This is also supported by the data from the COMPLETE study and suggests that any overall survival benefit associated with etoposide use in patients with PTCL is at best modest [8].

CD30 is expressed in all sALCL and among other nodal variants of PTCL its expression is variable from $58-64 \%$ in PTCL NOS and 43-63\% in AITL. Brentuximab vedotin (BV, Adcetris) is an antibody-drug conjugate active against CD30-positive lymphomas. The ECHELON-2 trial included a randomized, double-blind, phase 3 study of Brentuximab vedotin and $\mathrm{CHP}(\mathrm{A}+\mathrm{CHP})$ versus $\mathrm{CHOP}$ in the frontline treatment of patients with CD30+ PTCLs [9].
The A+CHP schedule showed superior PFS and significantly longer OS than CHOP in patients with nodal CD30+ PTCLs. The trial also demonstrated improvement in the complete remission rate $(68 \%$ vs $56 \%)$, and overall response rate $(83 \%$ vs $72 \%$ ) with A+CHP. Adverse events, including fatal AEs, were similar between groups. Of note, consolidative SCT was given to $22 \%$ patients in the $\mathrm{A}+\mathrm{CHP}$ group and to $17 \%$ in the CHOP group. The treatment with ASCT did not affect PFS nor OS rates.

The NCCN guidelines suggest the following treatment regimens as first line therapy: $\mathrm{BV}+\mathrm{CHP}$ regimen for sALCL cases; in other tumor histologies (PTCL NOS, AITL, nodal PTCL TFH), suggested regimens are as follows: $\mathrm{BV}+\mathrm{CHP}$ for CD30+ histologies, and CHOP or CHOEP for other histologies, according to the patient's age and performance status. As first-line consolidation high-dose therapy and stem cell rescue may be considered in appropriate patients [10].

High dose chemotherapy followed by autologous stem cell transplantation (ASCT) is a reasonable treatment option as front-line consolidation with resulting OS rates of 54\% to $68 \%$ and low non-relapse mortality. A major problem is early relapse/progression in up to $40 \%$ of patients starting first-line therapy. In the relapse situation the overall prognosis is dismal, and the best treatment has not been defined yet $[11,12]$. Chemorefractory patients should proceed to allogeneic SCT (allo-SCT) whenever possible, and the use of single agents as a bridge to transplant for these patients may be more appropriate because there is a need to sustain response until a compatible donor is identified and worked up [10-13].

Clinical practice recommendations on indication and timing of hematopoietic stem cell transplantation have recently been published by the American Society for Blood and Marrow Transplantation [14]. Registry studies on the role of autologous and allogeneic transplantation in PTCL have also been the subject of recent publications [15-17].

The current EBMT indications for hematopoietic transplantation in PTCL are illustrated in Table 2 [18].

To examine the real-world outcomes for patients with PTCL who underwent hematopoietic stem cell transplantation in our institution we conducted a retrospective review and report the clinical outcomes of 26 consecutive patients who were treated either as first-line consolidation or in the relapse setting between January 2000 and July 2018.

Table 2. EBMT indications for HSCT in PTCL [18]

\begin{tabular}{|l|l|l|l|l|}
\hline Disease status & MSD allo & MUD allo & MMAD allo & Auto \\
\hline CR 1 & CO/II & CO/II & GNR/III & CO/II \\
\hline Chemosensitive relapse, $\geq$ CR2 & S/II & S/II & CO/III & Co/II \\
\hline Refractory & CO/II & CO/II & CO/III & GNR/III \\
\hline
\end{tabular}

CO: clinical option

S: standard of care

GNR: generally not recommended
Grade I: at least 1 randomized trial

Grade II: at least 1 well-designed non-randomized CT

Grade III: expert opinion 


\section{Patients and methods}

Twenty-six patients were identified, with a median age of 46 years. Ninety-two percent of patients presented with advanced-stage at diagnosis (Ann Arbor stage III or IV) and $38 \%$ had B symptoms. The age-adjusted IPI (aaIPI) was low-intermediate in 15 patients and intermediate high/high in 11 patients (Table 3 ).

Table 3. Clinical characteristics of the patients at diagnosis $(\mathrm{n}=26)$

\begin{tabular}{|c|c|c|}
\hline \multirow[b]{2}{*}{ Characteristics } & \multicolumn{2}{|c|}{ Patients } \\
\hline & No. & $\%$ \\
\hline $\begin{array}{l}\text { Age, years } \\
\text { Median } \\
\text { Range }\end{array}$ & & \\
\hline $\begin{array}{l}\text { Sex } \\
\text { Male } \\
\text { Female }\end{array}$ & $\begin{array}{l}10 \\
16\end{array}$ & $\begin{array}{l}39 \\
61\end{array}$ \\
\hline B sypmtoms & 10 & 39 \\
\hline Clinical stage III to IV & 24 & 92 \\
\hline BM involvement & 9 & 34 \\
\hline $\begin{array}{l}\text { aalPI score } \\
\text { Low } \\
\text { Intermediate low } \\
\text { Intermediate high }\end{array}$ & $\begin{array}{l}7 \\
8 \\
11\end{array}$ & $\begin{array}{l}27 \\
30 \\
43\end{array}$ \\
\hline $\begin{array}{l}\text { Histologic subtype } \\
\text { AILT } \\
\text { PTCL-NOS } \\
\text { ALK-negative ALCL } \\
\text { ALK-positive ALCL } \\
\text { PTCL-with TFH phenotype }\end{array}$ & $\begin{array}{l}12 \\
5 \\
6 \\
1 \\
2\end{array}$ & $\begin{array}{c}46 \\
20 \\
23 \\
3 \\
7\end{array}$ \\
\hline
\end{tabular}

Abbreviations: AILT, angioimmunoblastic T-cell lymphoma; ALCL, anaplastic large-cell lymphoma; ALK, anaplastic lymphoma kinase; aaIPI, age-adjusted International Prognostic Index; BM, bone marrow; PTCL-NOS, peripheral T-cell lymphoma, not otherwise specified

According to the 2016 revision of the WHO classification of lymphoid neoplasms, the most common PTCL subtypes within our cohort were AILT (46\%), ALCL (26\%) and PTCL NOS (20\%) (1).

Most patients received $\mathrm{CHOP}$ chemotherapy as induction treatment regimen, with CHOEP being less frequently used (Table 4).

Twenty-seven transplants were performed in 26 patients (one patient had an ASCT followed by an allo-SCT after relapsing).

Nineteen patients had an ASCT with the BEAM conditioning regimen (Fig. 1). Sixteen patients were given an ASCT upfront as consolidation after induction treatment, with 14 being in CR and 2 in PR. Of these 16 patients, 5 had a relapse after ASCT and none survived, even though one was given an allo-SCT. Of the 3 patients given an ASCT as rescue treatment for relapse, 2 are alive in CR.
Seven patients underwent an allo-SCT, of whom 4 had it upfront and 3 after relapsing from a previous ASCT (Fig. 2). All patients received tacrolimus plus mycophenolate mofetil as GvHD prophylaxis and ATG was added to the conditioning regimen of the 2 patients transplanted with a mismatched unrelated donor. Five patients were conditioned with the Flu Mel protocol, 1 with Flu 2Gy TBI and 1 with the Flu BiCNU Mel protocol. All 4 patients treated upfront were given a transplant from unrelated donors of whom 1 was a 9/10 mismatch, none relapsed and all are alive. Of the 3 patients having a transplant after relapse, 2 are alive with no evidence of disease and one died of transplant related mortality.

\section{Table 4. Treatment lines used in PTCL patients}

\begin{tabular}{|l|l|l|}
\hline 1st line & $2^{\text {nd }}$ line & $3^{\text {rd }}$ line \\
\hline CHOP (14) & ESHAP (6) & Brentuximab (2) \\
\hline CHOEP (4) & Gem0x (2) & Gemcitabine (1) \\
\hline $\begin{array}{l}\text { CHOP + } \\
\text { alemtuzumab (3) }\end{array}$ & Brentuximab (1) & - \\
\hline CHOP + RT (2) & - & - \\
\hline ESHAP (2) & - & - \\
\hline R-ICE (1) & - & - \\
\hline
\end{tabular}

Figure 1. Flow diagram of treatment and outcome of patients submitted to ASCT

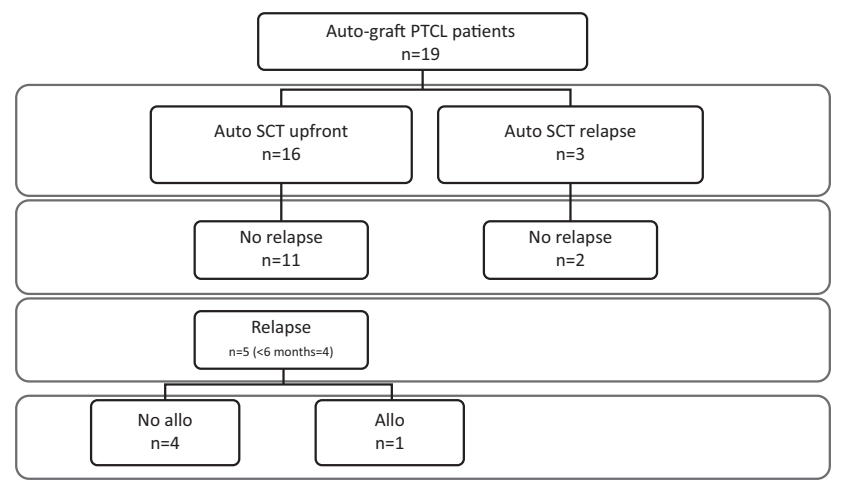

Figure 2. Flow diagram of patients submitted to allo-SCT

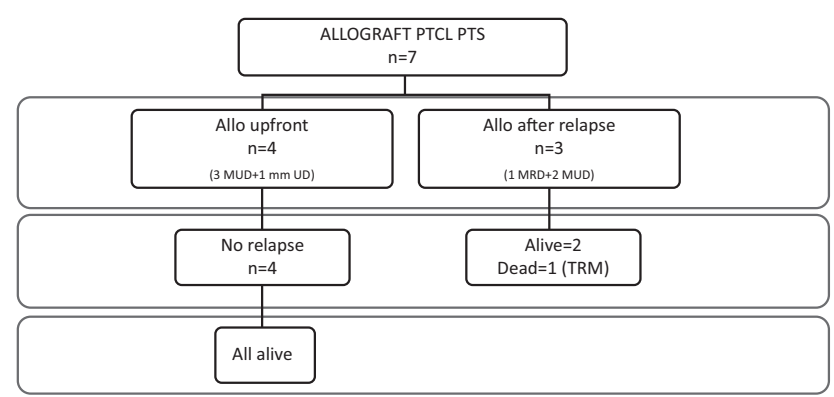


Two patients deserve a special mention:

- Patient 19, a 58-y.o. male had a diagnosis of classic Hodgkin's disease (cHD) in 2009, was treated with 8 cycles of ABVD and relapsed in 2011 being treated with ICE followed by ASCT at another institution. In 2013, he presented with PTCL AITL subtype infiltrated with EBV + B cells and was treated with R-ICE before being submitted to a matched unrelated alloSCT in CR.

- Patient 21, a 42-y.o. male patient had a diagnosis of cHD in 1995, and achieved complete remission after 6 cycles of ABVD. He had a localized relapse of cHD in 1999, treated with local radiotherapy. He then presented in 2015 with a PTCL AITL subtype infiltrated with EBV+ B cells and CNS infiltration. He was treated with ESHAP followed by the LMB-96 protocol and was then submitted to a mismatched unrelated alloSCT in CR.

Both patients are alive, one with moderate cGvHD.

\section{Results}

We evaluated the overall survival (OS) and progression-free survival (PFS) in our cohort of patients. The median follow-up time was 6.3 years (1-18.1 years). OS was calculated from the date of diagnosis until death due to any cause, and PFS was measured from transplant until relapse, progressive disease or last follow-up. Survival-based analysis were performed with the Kaplan-Meier methodology with censoring as appropriate and were evaluated with a log-rank test, with a 2 -tailed $\mathrm{P}$ value $\leq .05$ used to reject the null hypothesis.

Nineteen patients underwent ASCT, of whom 16 (8 AITL, 4 PTCL NOS, 4 ALCL) as upfront consolidation treatment and 3 (2 ALCL, 1 AITL) for relapsed disease. Fifteen of the patients having an ASCT upfront were in CR1 and 4 relapsed, all within 6 months of transplant; the patient transplanted upfront in PR is alive in CR.

Three patients had an ASCT as rescue for recurrent disease, 1 died with relapse and 2 are alive in CR.

The OS and RFS at 6-years for the 19 patients having an ASCT are $62 \%$ and $59 \%$, respectively.

A

os

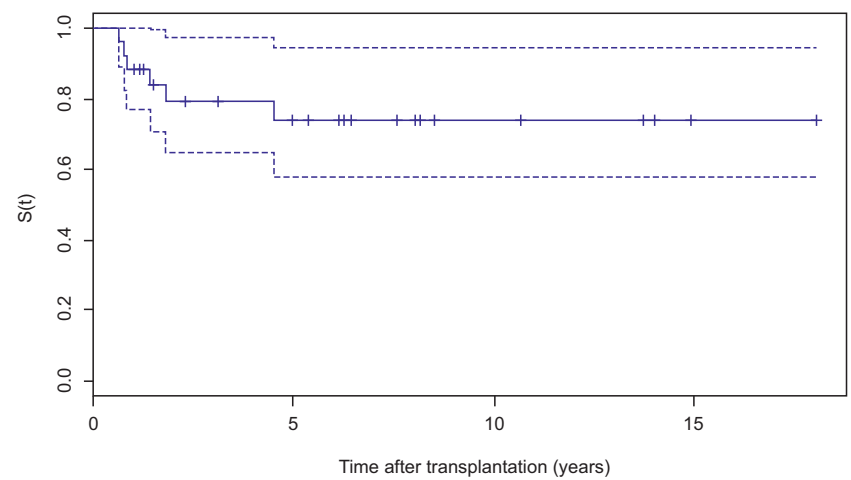

Seven patients had an allograft. Four (2 AITL, 1 ALCL, 1 NOS) as upfront consolidation, of whom 3 with a matched unrelated donor and 1 with a mismatched unrelated donor. They all are alive in CR.

Three patients (2 AITL, 1 PTCL NOS) had an alloSCT after relapsing. Two with an unrelated donor, after having failed an ASCT, and 1 with a matched sibling. Two are alive in CR and 1 died due to transplant-related complications.

Chronic GvHD was the most relevant complication observed in $50 \%$ of patients submitted to allo-SCT. It resolved in all except 2 patients who still have cGvHD needing immunosuppression.

The OS and RFS at 6-years for the 7 patients submitted to allo-SCT are $87 \%$ and $85 \%$, respectively.

Transplant-related mortality (TRM) was $3.7 \%$ for the entire population. Out of the 26 patients, seven patients died, 6 with progressive disease after auto HSCT and 1 with multiorgan failure after allo-HSCT.

The 6-year OS and PFS for the entire population were $74 \%$ and 69\% respectively (Fig. 3). Overall survival and PFS for patients submitted to ASCT and allo-SCT were similar, as shown in Fig. 4.

\section{Conclusions}

The results of this retrospective study, taking into account the adverse risk profile of the population, suggest that autologous/allogeneic stem cell transplantation is an effective and safe option for the consolidation of patients with PTCLs.

The recently published results of the COMPLETE consortium analyzed the impact of ASCT on the clinical outcomes of patients with newly diagnosed nodal PTCL in CR1 patients. They suggested that certain subgroups of patients with PTCL, i.e. those with AITL and/or high-risk features (advanced-stage disease or intermediate-to-high IPI scores) might benefit from consolidative ASCT in CR1 [19]. Still they concluded that the broader applicability of this strategy should be determined in prospective, randomized trials.
B

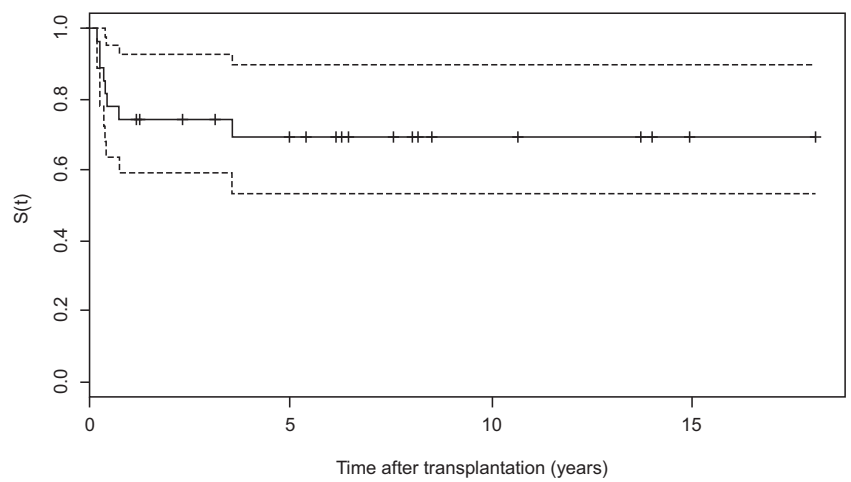

Figure 3. Kaplan-Meier estimates of 6-year 0S (A) and PFS (B) for the entire patient population 

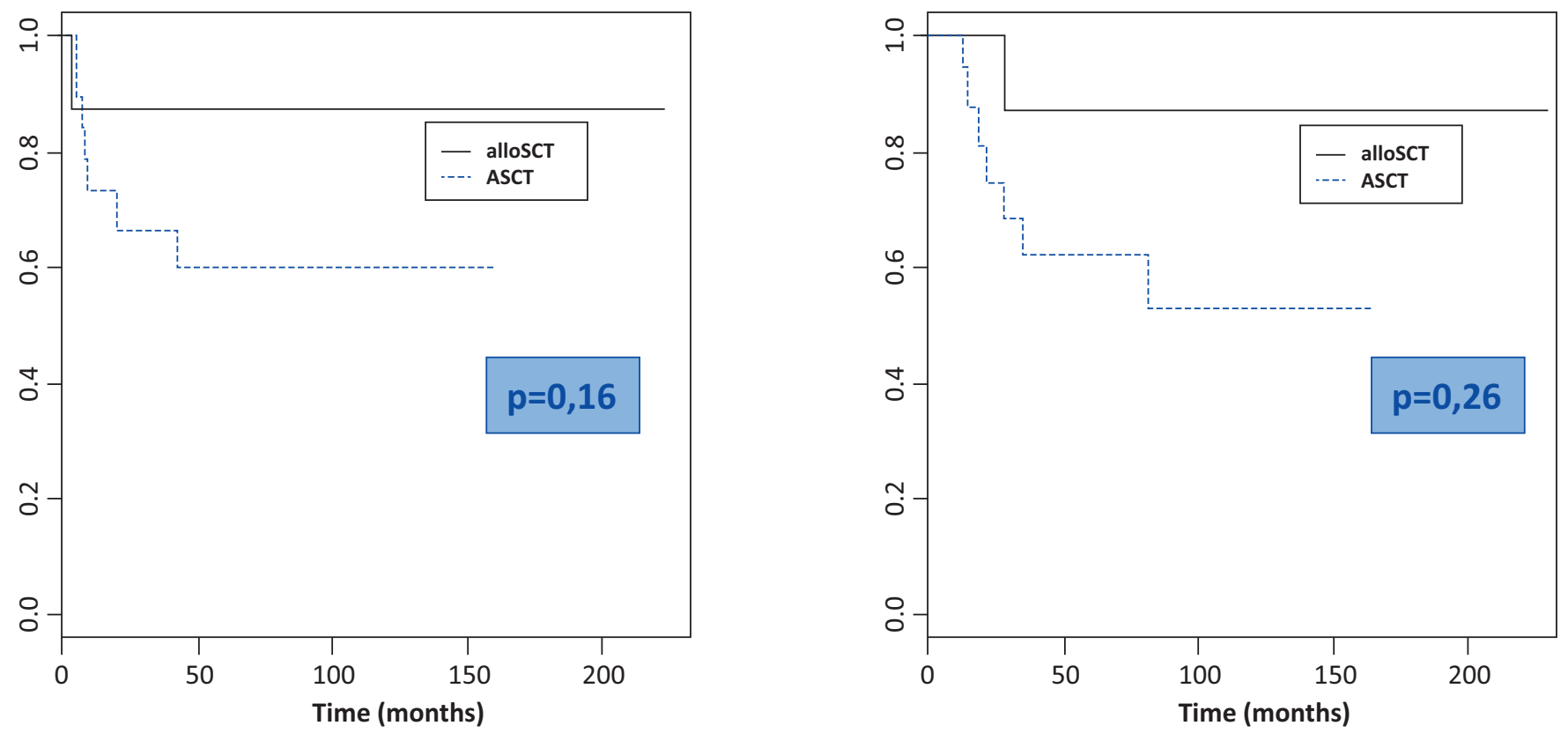

Figure 4. Kaplan-Meier estimates of overall survival and relapse free survival of PTCL patient cohorts submitted to autologous and allogeneic transplantation

In our small study, some key questions remain on the real role of ASCT and allo-SCT in PTCL. Notwithstanding these limitations our study shows that HSCT is feasible and may benefit patients with high risk PTCL. The outcomes did not differ significantly between ASCT and allo-SCT approaches, but the latter is probably more effective in patients with refractory disease.

These results need to be validated in prospective studies, including a larger number of patients and may provide a platform for designing future and larger studies on the role of HSCT in PTCL.

\section{Conflict of interest}

M. Abecasis is in the speakers bureau of Takeda.

\section{References}

1. Swerdlow SH, Campo E, Pileri SA, Harris NL et al. The 2016 revision of the World Health Organization classification of lymphoid neoplasms. Blood 2016; 127: 2375-2390.

2. Moskowitz AJ, Lunning MA, Horwitz SM. How I treat the peripheral T-cell lymphomas. Blood 2014; 123: 2636-2644.

3. Wilcox RA. Optimising initial treatment for peripheral T-cell lymphoma: a tough nut to CHOP. Lancet Haematol. 2018; 5: e182-e183.

4. Savage KJ, Chhanabhai M, Gascoyne RD, Connors JM. Characterization of peripheral T-cell lymphomas in a single North American institution by the WHO classification. Ann Oncol 2004; 15: 1467-1475.

5. Vose J, Armitage J, Weisenburger D. International peripheral T-cell and natural killer/T-cell lymphoma study: pathology findings and clinical outcomes. J Clin Oncol 2006; 24: 2472-2479.
6. Schmitz N, Trumper L, Ziepert M, Nickelsen $M$ et al. of mature T-cell and NK-cell lymphoma: an analysis of patients with T-cell lymphoma treated in studies of the German High-Grade Non Hodgkin Lymphoma Study Group. Blood 2010; 116: 3418-3425.

7. Ellin F, Landstrom J, Jerkeman M, Relander T. Real-world data on prognostic factors and treatment in peripheral T-cell lymphomas: a study from the Swedish Lymphoma Registry. Blood 2014; 124: 1570-1577.

8. Carson KR, Horwitz SM, Pinter-Brown LC, Rosen ST et al. A prospective cohort study of patients with peripheral T-cell lymphoma in the United States. Cancer 2017; 123 : 1174-1183.

9. Horwitz S, O'Connor OA, Pro B, Illidge T, Fanale $\mathrm{M}$ et al. ECHELON-2 Study Group. Brentuximab vedotin with chemotherapy for CD30-positive peripheral T-cell lymphoma(ECHELON-2): a global, double-blind, randomised, phase 3 trial. Lancet. 2019; 393:229-240.

10. National Comprehensive Cancer Network. NCCN Clinical practice guidelines in oncology for Non-Hodgkin's Lymphomas. Version 2.2019.

11. Schmitz N, de Leval L. How I manage peripheral T-cell lymphoma, not otherwise specified and angioimmunoblastic T-cell lymphoma: current practice and a glimpse into the future. Br J Haematol 2017; 176: 851-866.

12. Zain JM. Aggressive T-cell lymphomas: 2019 updates on diagnosis, risk stratification, and management. Am J Hematol 2019; 94: 929-946.

13. Schmitz N, Lenz G, Stelljes M. Allogeneic hematopoietic stem cell transplantation for T-cell lymphomas. Blood 2018; 132: 245-253.

14. Kharfan-Dabaja MA, Kumar A, Ayala E, Hamadani M, et al. Clinical practice recommendations on indication and 
timing of hematopoietic cell transplantation in mature $\mathrm{T}$ cell and NK/T cell lymphomas: an international collaborative effort on behalf of the guidelines committee of the American Society for Blood and Marrow Transplantation. Biol Blood Marrow Transplant. 2017; 23(11):1826-1838.

15. Rohlfing S, Dietrich S, Witzens-Harig M, Hegenbart U et al. The impact of stem cell transplantation on the natural course of peripheral T-cell lymphoma: a real-world experience. Ann Hematol 2018; 97: 1241-1250.

16. Fossard G, Broussais F, Coelho I, Bailly S et al. Role of up-front autologous stem-cell transplantation in peripheral T-cell lymphoma for patients in response after induction: an analysis of patients from LYSA centers. Ann Oncology 2018; 29: 715-723.

17. Epperla N, Ahn KW, Litovich C, Ahmed A et al. Allogeneic hematopoietic cell transplantation provides effective salvage despite refractory disease or failed prior autologous transplant in angioimmunoblastic T-cell lymphoma: a CIBMTR analysis. J Hematol Oncol 2019; 6: doi: 10.1186/s13045-018-0696-z.
18. Duarte R, Labopin M, Bader P, Basak GW et al. Indications for haematopoietic stem cell transplantation for haematological diseases, solid tumors and immune disorders; current practice in Europe, 2019. Bone Marrow Transplant 2019; 54: 1525-15.

19. Park SI, Horwitz SM, Foss FM, Pinter-Brown LC, Carson KR et al. The role of autologous stem cell transplantation in patients with nodal peripheral T-cell lymphomas in first complete remission: report from COMPLETE, a prospective, multicenter cohort study. Cancer 2019; 125:1507-1517.

\title{
Трансплантация стволовых клеток как консолидирующее лечение при периферических Т-клеточных лимфомах
}

\author{
Мануэль Абекасис, Каталина Гомез, Изабелина Феррейра, Мария Гомес да Силва, Нуньо Миранда, \\ Гилда Тейксейра, Фернандо Леаль да Коста, Мария Жоао Гутьеррез \\ Португальский институт онкологии Франциско Жентиль, Лиссабон, Португалия
}

\section{Резюме}

Периферические Т-клеточные лимфомы (ПТКЛ) являются гетерогенной группой редких агрессивных лимфом, состоящей из более чем 20 различных клинических форм и представляющих около $10 \%$ всех неходжкинских лимфом, диагностированных в Западном мире. Учитывая их гетерогенность, отсутствует консенсус, касающийся наилучшего лечения первой линии, роль аутологичной или аллогенной трансплантации гемопоэтических клеток (ТГСК) в качестве консолидации пока противоречива. Чтобы изучить реальные исходы у пациентов с ПТКЛ, направленных для ТГСК в наше учреждение, мы ретроспективно изучили клинические исходы у 26 пациентов, которым выполняли трансплантацию либо в качестве консолидирующей терапии первой линии или при рецидиве заболевания в период с января 2000 по июль 2018 г. Медианный срок наблюдения составлял 6,3 года; 19 больных получили ауто-ТГСК, 16 - в качестве первой консолидации и 3 - по поводу рецидива болезни. Общая выживаемость $(\mathrm{OB})$ и безрецидивная выживаемость (БРВ) были, соответственно, 62\% и 59\%. Семи больным было проведена алло-ТГСК, четыре - консолидация первой линии и трем - после рецидива. Шесть больных живы и один умер в связи с процедурой ТГСК. Этот вид летальности составил 3.7\% для всей группы, а 6-летние показатели ОВ и БРВ были, соответственно, 74\% и 69\%. Наши результаты предполагают, что аутологичные и аллогенные ТГСК являются эффективным и безопасным вариантом в целях консолидации больных ПТКЛ с неблагоприятным профилем риска, но нужна их валидация в проспективных исследованиях, включающих большое число пациентов.

\section{Ключевые слова}

Периферические Т-клеточные лимфомы, терапия первой линии, СНОР, Брентуксимаб ведотин, трансплантация гемопоэтических клеток, аллогенная, аутологичная. 